Techniques \& Culture

De l'Himalaya au haut Atlas. De l'Asir aux Andes

\title{
Présentation
}

\section{Martine Garrigues-Cresswell}

\section{OpenEdition}

Journals

Édition électronique

URL : https://journals.openedition.org/tc/899

DOI : $10.4000 /$ tc. 899

ISSN : 1952-420X

\section{Éditeur}

Éditions de l'EHESS

\section{Édition imprimée}

Date de publication : 1 septembre 1986

ISSN : 0248-6016

\section{Référence électronique}

Martine Garrigues-Cresswell, «Présentation », Techniques \& Culture [En ligne], 7| 1986, mis en ligne le 23 janvier 2006, consulté le 29 septembre 2022. URL : http://journals.openedition.org/tc/899 ; DOI : https://doi.org/10.4000/tc.899

Ce document a été généré automatiquement le 29 septembre 2022.

Tous droits réservés 


\section{Présentation}

Martine Garrigues-Cresswell 